\title{
Etnikum és hatalom az Andokban (Letenyei László)
}

ERedeti MegJelenéSe: ReplikA, 29. ÉVf.

(1998) 83-96

„Szálanként tépte le Araukániáról

a büszke tollakat az alkohol,

lesöpörte a söntés,

eltakarta a mindenféle ügynök

a rabló hódítók szolgálatában,

[...]

Így pusztult az indián észrevétlen,

s nem is látta, ahogy kótyavetyélték

örökségét: a zászlókat se látta,

nem zúdított nyílesôt a hajókra,

amíg apránként lassan összezúzták

tisztviselók, tolvajok, földesurak.

[...]

Tündökletes mezitlenségét,

arany mellét, sápatag derekát, vagy

ásványokból felfüzött ékszerét, mely

minden csepp harmatot bôrére gyüjtött,

igy változtatták rongyos hacukává,

foltozott, hosszú nadrágokba dugták.

[...] 
Megfoghatatlanul történt, akár az

áruló lépte, vagy a rák a testben, amig földig görnyesztették apánkat, megmutatták neki a ködvilágot s belépett amaz egyetlen kapun, mely nyílott neki, s nyílik minden szegénynek, minden nyomorult szegénynek e földön."

\section{(Pablo Neruda: A teljes Ének - RÉSZlet \\ SOMLYó GYÖRGY FORDÍTÁSA)}

Egy andokbeli kisvárosban történt, Otavalóban. Ketten voltunk Joeval, és éppen befordultunk a piac melletti szúk utcába, amikor a járdán egy idôs, kendôs nénike tûnt fel velünk szemben. Kicsi volt, és szinte a földig görnyedt az óriási batyu alatt, amit a hátán cipelt. Egy pillanatra kedvet is éreztem megkérdezni tóle, ne segítsem-e vinni a csomagot (szerencséd, hogy öreganyádnak szólítottál), de ez persze lehetetlen volt, részben a nyelvi akadályok miatt (hogy mondják az öreganyát kecsuául?), részben pedig azért, mert arrafelé jobbára csak a tolvajok szokták elvenni mások csomagját, de ók nem segítségképpen. A mesebeli párbeszéd elmaradt. A járda viszont nagyon is valóságos volt, szögletes betonkockákból, elég keskenyre építve ahhoz, hogy hárman már ne férjünk el egymás mellett. Ilyenkor nyilván nekünk, a két fiatalnak kell lelépnünk egy pillanatra az úttestre, a paradicsomárus nôk és a rendetlenül parkoló autók közé, hogy helyet adjunk - gondoltuk. De mire végiggondoltuk, a néni már megelôzött minket: hirtelen mozdulattal lépett oldalra, és szerényen, ránk sem pillantva jelezte, hogy szabad az út. Számára természetes volt, hogy ebben a helyzetben ô, az egyszerú indián öregasszony ad utat. A gringónak. 
Az ott töltött hónapok alatt sem tudtam hozzászokni,

- hogy a buszon nem adjuk át a helyünket a szoptató indián mamának, aki a többi kicsit a hátára kötözve hordja, és úgy néz ki, mint egy színes banánfürt. Viszont átadjuk a fiatal kreol lánynak, aki mosolyog, és a mamára pillantást sem vetve leül az ülésre;

- hogy egy hatévesforma indián gyerek görnyed a lábunkhoz, hogy kipucolja a cipoonket. Pedig mi csak azért engedjük, hogy megalázza magát, mert a remélt fél sol borravalóért már öt perce kiabál ránk, hogy piszkos, piszkos, mármint a cipô, amit alkalmasint egy kollégája pucolt meg, két sarokkal arrébb;

- hogy elôre köszönnek, vagy ha megelôzzük óket a köszönésben, akkor kétszer viszonozzák. Jó napocskát, nagyon jó napocskát... Mert mindig mindent becézgetnek.

És ha megszeretnek, akkor téged is becéznek, de úgy, hogy egy pillanatra sem felejtik el, hogy más világból jöttél: gringócska.

\section{Történelem}

Mindezek a jelenségek a világ egyik legôsibb kasztrendszerének napjainkig élô maradványai. Talán az andokbeli gyarmati uralom is csak elfogadta, átvette az Inka állam etnikai alapú szervezési elvét, ahol az Inka kijelölte az egyes etnikumok helyét a munkamegosztás rendjében, ahol mindegyik csoport saját viseletet, mesterséget és mindezeknek megfelelố státust és kulturális identitást kapott az Inkától. A krónikás által lejegyzett Inka eredetmítosz szerint:

Manco Capac inca letelepitvén népeit, a földmüvelés, házépités, csatornázás és az emberi életben szükséges egyéb teendók tanításával együtt oktatta alattvalóit, udvariasságra, társas életre. [...] Minden tartománynak és 
nemzetnek meghagyta: ne nagyon hasonlitsanak hozzá, az Inkához, legyen közte és közöttük észrevehetô különbség. Így megparancsolta, hogy egyesek füles sapka módjára viseljék a hajukat, oly módon, hogy a homloktól a halántékig fejük szabadon maradjon, kétoldalt azonban a haj a fül legalsó részéig érjen. Másoknak megparancsolta, hogy viseljenek a fül közepéig érö copfot, megint mások még rövidebbet, de senki se hordja a haját annyira rövidre nyírtan, mint az inka. [...] Különböznie kellett családi nevek és tartományok szerint a fülbevalónak is, amit viseltek. Meghagyta a Mayo és Cancu nemzetségnek, hogy hordjon kisujjnyi vastagságú pálcácskát. [...] Az Urcos, Yucay, Tampu családoknak, valamennyien a Yucay folyón túlról valók, különös kegyelme és jóindulata gyanánt megengedte, hogy a többi nemzetségnél nagyobb fület viselhessenek, amely azonban a felét se érje el az Inkáénak.

A jelvényeknek az inka által megszabott különbözósége arra szolgált, hogy a nemzetségeket és családokat ne lehessen összetéveszteni. De ezen felül, mint a hübéresek mondják, a különbségnek más jelentôsége is volt, éspedig: minél jobban hasonlított jelvényük a királyéhoz, annál nagyobb kiváltság és elismerés jele volt. (Garcilaso de la Vega 1964 [1609]: 51; Szokoly Endre fordítása)

A kasztrendszer a gyarmati uralom alatt tökéletesedett. A gyarmat a két egymás mellett élố társadalom, a hódítók és a meghódí tottak ellentétén alapult, ahol az alkirályi adminisztráció játszotta a mérleg nyelvének szerepét. A két társadalom jogi meghatározása (a Spanyol Nemesi Köztársaság és az Indián Nemesi Köztársaság) etnikai alapon történt. A Spanyol Köztársaság azért jöhetett létre, mert az Újvilágban már minden európai spanyolnak számított, még ha gyakran baszk, portugál vagy éppen magyar származásúak voltak is, a Habsburg Birodalom különbözó vidékeirôl. Hasonlóképpen: az ôslakók, akik szintén más-más etnikai csoportokhoz tartoztak, az új rendszerben indiánként részesültek azonos bánásmódban (lásd a Replika jelen számában Xavier Albó írását). Csak a kurakák, a nemességgel és előjogokkal fölruházott vidéki indián elókelôk tudták átmenteni 
hatalmuk egy részét. A kurakák és a spanyol nemesek voltak a nem adóköteles rendek, az indiók pedig a dolgozó rend.

Francisco de Toledo alkirály rendeletei módszeresen számolták föl az ôshonos identitás legfontosabb elemeit (Toledo 1989 [1570_ 1580]: 190, 228). Toledo bámulatos érzékkel tiltotta be a felületes megfigyelô számára jelentéktelennek tûnô apróságok egész sorát: bizonyos textiltechnikákat, mint az ikatolás, egyes szövésmintákat, olyan viseleteket, mint a tunika, egyes edényfajtákat, mint az arybalus, a testfestést, a csontfurulyákat, bizonyos nagyságú dobokat, a rituális táncos verekedést - és még a kecsua nyelvet is. Elrendelte ugyanakkor azt is, hogy a falvak lakói mind a maguk viseletét hordják, s hogy ez a viselet nem emlékeztethet az Inka-korra (del Busto 1964). A ma ismert ôshonos népviseletek, a poncsó, az asszonyok bô szoknyája, a füles sapka és a kalap e rendelet hatására terjedtek el Andokszerte.

Két társadalom élt tehát egymás mellett. A feketékkel együtt, akik a nagy udvarházak kapuin belül, és ezzel a társadalmon kívül rekedtek, három. És ezek keveredései, ami legalább hat, csak a tiszta kombinációkat számolva. Tiszta kombinációk viszont évszázadok óta nincsenek. Végtelen számú kombináció létezik, végtelen, erre vonatkozó ismerettel. Már régen nem valamilyen etnikummal szembeni elôítéletrốl, stigmáról, vagy megfordítva, valamilyen etnikai csoport alkalmazkodási, érdekérvényesítési gyakorlatáról van szó, hanem az etnikai elemek különbözô mértékú adagolásáról és a keverési arányok jó vagy rossz (ízlés szerinti) megválasztásáról. A vegyülés még nem egynemúsödés, és nemcsak a genetikailag különbözô törzsek közeledése egymáshoz, hanem roppant nagyszámú kombináció létrejötte, amelynek a kezdő és végpontjain ma éppen úgy „büszkeszomorú indiánok”, „mozgékony európaiak” vagy „félpogány feketék" állnak, mint akár ötszáz évvel ezelôtt.

A függetlenség kivívása után a fiatal köztársaságok jogilag eltörölték a kasztrendszert, gyakorlatilag viszont az új berendezkedés egyenjogú polgárai csak a városiak, a múveltek, a tulajdonnal rendelkezôk, 
etnikai kifejezéssel: a kreolok és a meszticek lehettek. (Latin-Amerika több országában az ôshonos lakosság még állampolgárságot sem kapott a függetlenség múlt századi kivivása után, sốt, egyes középamerikai országokban még a 20. század hetvenes éveiben is ez volt a helyzet.) Mint arra a jelen válogatás egyik szerzóje rámutat, a függetlenségi háború leginkább arra szolgált, hogy a megerôsödô kreol csoportok abból is kiforgassák az ôshonos lakosságot, amit a gyarmati rend Indián Nemesi Köztársasága még biztosított a számukra (Carlos Ivan Degregori, történész, az IEP francia-perui kutatóintézet kutatója, egykoti igazgatója, 1993). A felszabadulás ebben az olvasatban egyszerúen a Spanyol Nemesi Köztársaság gyốzelme a levert felkeléseiben meggyöngült Indián Köztársaság felett. A lázadásokat követố megtorlásokban a kuraka rend fölmorzsolódott, megsemmisült, ami fölöslegessé tette a gyarmati intézményeket.

Juan Carlos Estenssoro (jelenleg a párizsi CNRS-ben dolgozó fiatal perui múvészettörténész) egy viszonylag rövid - de az Andok történelmében sorsdöntố, a 18. század végétôl a 19. század közepéig terjedô - idôszak kulturális életének egyik központi elemét, a zene és a tánc világát, a fiestakultúrát veszi szemügyre. Estenssoro nyomán talán jobban megértjük, mit is jelenthettek a hétköznapokban a Degregori által messzirốl és nagy vonalakban fölvázolt történelmi folyamatok. Szemléletesen mutatja be a 18. századi indián forradalom és szabadságharc leverése utáni egyházi és világi hadjáratot a tánc és a jókedv, pontosabban az ôshonos lakosság és a városi szegények kulturális reprezentációja ellen, az elit fokozatos kivonulását az ünnepból és visszavonulását az utcáról a privát báltermekbe.

A független andokbeli államok társadalmi programja az ôshonos parasztok és törzsi közösségek asszimilációja, a városiasodás és polgárosodás, etnikai jellegú terminussal a meszticizálódás lett. Degregori a jelenkor folyamatairól írván szókimondóan - az Andokban egyedüliként - rántja le a leplet a meszticizálódás valótlan, rózsaszínre pingált hivatalos felfogásáról, és helyette egy új fogalmat ajánl, a kényszerúen vállalt kifehéredést (blancamiento). Tanulmányában az 
indiánsággal, a baloldalisággal, a társadalmi mozgalmakkal és a városi középosztállyal kapcsolatos problémákat járja körül.

A nemzeti gondolat megszületése és a jog elốtti egyenlőség még távolról sem jelentette az „etnikai közigazgatás”, azaz az etnikai alapú vidéki közigazgatási gyakorlat megszúnését, a kasztrendszer még sokáig fennmaradt (Andrés Guerrero, marxista mozgalmárként is ismert újságíró és kutató, 1993). Századunkban az állam - mivel már erôsebben és hatékonyabban tudta érvényesíteni a maga asszimilációs és nemzetépítố törekvéseit - arra használta föl az iskolai oktatást és a nemzeti médiumokat, hogy a spanyol alapú egységesedés jegyében visszaszorítsa az ôshonos világot. A társadalmi viselkedést azonban napjainkig is az etnikai alapú kasztszemlélet uralja. A választott írás az ecuadori „indiánügy” történetét beszéli el a gyarmati kor végétôl 1990-ig, az egész országot megrengetô ôshonos felkelésig.

\section{Napjainkban}

A Középsô-Andok országai, Ecuador, Peru és Bolívia sokak szerint mesztic országok. A tévét nézve még skandináv országoknak is hihetném ôket, mert a bemondónôk, a szereplôk, a képernyốn megjelenô politikusok, iparbárók és befolyásos emberek mind-mind szốkék és kék szemúek, legfeljebb némi mediterrán beütéssel. Kreolok. Simon Bolívar szavaival „az ország urai”, még ha nimbuszukat megtépázták is olyan malôrök, mint az arab származású elnök választási gyôzelme Ecuadorban, vagy az, hogy Mario Vargas Llosa, az író, aki elnökjelöltként indult az 1995-ös perui választásokon, a vereség után megtagadta a nemzetiségét, és spanyol állampolgár lett.

A kreolok világának megvédéséért nagy árat kell fizetni: zárt klubhálózatok, rezidenciális negyedek, fizetett sofốrök, három-négy méter magas vaskerítések világa ez, olyan életeké, amelyekbe nem könnyú bepillantást nyerni. Kreol barátaim nem utaznak buszon, 
nem strandolnak közstrandon, nem járnak az utcán. Az utca, a strand, a busz - egy másik világ. Azt mondják, mesztic, ahová nagylelkúen besorolják a mulattokat, morenokat, zambitokat. A mesztic nem egy kaszt, hanem kasztok sokasága, amely spanyol dialektusok sokaságát beszéli, s e kasztokat semmi sem füzi össze, hacsak az nem, hogy egy másik világot ok együtt rekesztenek ki, ez pedig a falusi földutak, az egyterú és ablaktalan viskók, az óshonos nyelvek, a waraka, ohota, csujjo és alpargata világa, glóbuszunk oly kevés autochton kultúrái egyikének maradéka.

A kreol, a mesztic, a fekete, az óshonos (csak indiánt ne mondjunk, súlyos inzultusnak számít!) egyszerre etnikai és társadalmi rétegzôdési kategóriák. Egy részük a végbement vérkeveredésre utal (a tengerparti spanyol szleng ismeri a világon a legtöbb kifejezést az emberi borszín árnyalatainak leírására), másik részük pedig ártatlan szociológiai szakterminusnak túnik, az Andokban azonban etnikai jelentéstartalmat is hordoz.

Más etnikai kategóriák, mint például a csóló, a „városi indián”, relatív fogalmak. Argüedas szerint „mind keressük a magunk csólóját”, azt az embert, aki nálunk is csólóbb. Helyzettôl függôen bárki lehet csóló: egy középvezetô például a fônökének csóló, a munkásoknak azonban úr, és ố csólózhatja le ôket, függetlenül attól, hogy alkalmasint maga is beszél kecsuául, táncol huaynut, és magáénak vallja az ôshonos identitás számos elemét. „Apám és anyám még ilyenek voltak" - mondta Don Segundo, ecuadori házigazdánk, és egy indiánra mutatott. Tudniillik, hogy kék poncsós, egyszerú és sajnálatra méltó emberek voltak. Szemben vele, aki már nem hord népviseletet, és akinek van munkája (takarító az iskolában), azaz igazi városi ember, csóló.

A „paraszt”, a „városi”, a „tanító” és más rétegzôdési kategóriák etnikai kicsengésérôl ír Xavier Albó a Replikában. A katalán származású bolíviai antropológus az Andok egyik legismertebb kutatója, a La Paz-i CIPCA kutatóintézet munkatársa, mind tudósként, mind az ôshonos mozgalmak elhivatott támogatójaként hírnevet szerzett 
magának. A választott cikk Albónak nem a legújabb munkája, ám talán a legalkalmasabb arra, hogy az európai olvasó megértse, mit jelent ma indiánnak lenni - belülrôl és kívülállóként. A látszólag nyelvhasználati kérdés mélyen társadalmi. Az etnikai és társadalmi jelentéseket összemosó fogalmak egyfajta tudati kasztrendszerbe zárják az ajmarákat, ahol már az is nagyfokú mobilitásnak, sôt, áttörésnek számít, ha valaki parasztból bányásszá emelkedhet a társadalmi piramisban. De miért lenne törvényszerú, hogy az etnikai elnevezések gazdaságilag gúzsba kössenek egyeseket? Miért csak asszimiláció útján lehetne kitörni e hátrányos helyzetból? - tette föl a kérdést Albó az elsôk között, 1979-ben. Hogy ma mindezt az ajmara politikai mozgalmak is a zászlajukra túzték, egy kis részben biztosan Xavier Albó érdeme is.

Mint a legtöbb latin-amerikai szerzôre, rá is hatással volt a marxizmus, ám ô nem jó marxista: a marxista osztályfogalmakat alkalmatlanoknak tartja az ajmara világ leírására. Ugyanakkor korszerúbb teoretikus hagyományokra való hivatkozás nélkül is jó felkészültségre valló biztonsággal használja a Bourdieu munkásságából vagy antropológusok munkáiból ismert terminológiát (nyelv-mint-generáló, test-mint-generáló stb.).

A Középsô-Andok országai nem egyszerúen megkésettek a latinamerikai általános meszticizálódás, azaz az össznépi vérkeveredés, elspanyolosodás és közös identitás kialakításának útját járó országokhoz, például Mexikóhoz vagy Kolumbiához képest. Úgy túnik, megalakulásuk óta járnak egészen más úton. Sohasem volt elég nagyszámú bevándorló ahhoz, hogy a tényleges vérkeveredés végbemenjen (hivatalosan is csak „kulturális meszticizálódásról” beszélnek), és ilyen értelemben az indiánok tömeges jelenléte volt az, ami eltérô pályára sodorta ezeket az államokat: az óshonos parasztság tömegeit nem lehetett semmibe venni, feloldani, asszimilálni, meszticizálni. De a kiegyezés is elmaradt: soha nem volt olyan kormányzat, amely hajlandó lett volna átadni a hatalom egy részét a mindenkori ôshonos mozgalmak valamelyikének. A két világ szembenállása és e 
szembenálláshoz való állandó viszonyulás az andokbeli társadalmak olyan jellegzetessége, amely szinte ismeretlen más latinamerikai államokban.

\section{Falusiak, városiak, és városi falusiak}

A magyar olvasóközönség számára ismerôs dolog, hogy egyes országokban jelentốs különbségek lehetnek a falusi és városi lakosság életvitele, sốt, kulturális identitása között is. E különbségek az Andokban roppant hangsúlyosak: a „szokásos” városi-paraszt ellentétet itt nyelvi és etnikai elemek is átszövik: kissé leegyszerúsítve, a „vidéki” indiánt jelent, a „városi” pedig meszticet vagy kreolt, illetve, ahogy válogatásunk egyik szerzôje írja, a fehérmesztic világot. Mivel a nagyvárosok döntôen a Csendes-óceán partján fekszenek, a falusi népesség pedig a hegyvidéken él, a fenti különbségtételt gyakran az andokbeliek, a ,hegyi emberek” (serranos) és a tengerpartiak (costenos) különbségeként is értelmezik. Erre a megkülönböztetésre utal többször is Estenssoro, amikor - például - az andesi fiesta és a városi ünnep közötti különbségekrôl ír.

A nyolcvanas évektôl ez a helyzet megváltozni látszik. Az Andok valamennyi országában elképesztố méretú városiasodás, pontosabban városba vándorlás kezdôdött el. Quito lakosainak száma egy évtized alatt másfélszeresére duzzadt, La Pazé hasonlóképpen, Limáe pedig a korábbi három és fél millióról becslések szerint kilencmillióra gyarapodott. A városba áramlást a gazdasági okokon túl éppen az ôshonos kulturális mozgalmak erôsítették föl, amelyek elvitatták a kreol elit kizárólagos jogát a fớváros használatára. Az úgynevezett „új városlakók” tömegeit Lima már nem tudta asszimilálni: városban élố vidéki szubkultúrák alakultak ki (Adams és Golte 1987).

Ezzel egyidejúleg a város hagyományos értékei, a gyarmati építészet remekei pusztulásnak indultak. A jellegzetes limai palota egyemeletes, az utcai front zárt, az emeleten végig gazdagon faragott 
fa erkélyekkel, mediterrán tetôvel. Jellemzóek a nagy barokk vaskapuk, és az ablakokat védố kovácsoltvas rácsdíszek. Állítólag húsz éve még lefátyolozva jártak a limai hölgyek, tisztaság és rend uralkodott, a szórakozóhelyekrôl marinera és vals criollo, gitár és hárfa hangjai szúrốdtek az utcára.

Lima kreol arculata a baloldali diktatúra idején változott meg, $\mathrm{s}$ a változást fölgyorsították a nyolcvanas évek polgárháborús eseményei és az urbanizációs robbanás. „Ma már nincsenek limaiak”foglalta össze számomra egy taxisoför, aki maga is kicsi barna hegyi ember (serrano) volt. A házak lepusztultak, az emeletek lakhatatlanok, a legtöbb helyütt hiányzik a tetô, leszakadt a több száz éves faragott balkon. A földszinti helyiségeket a hegyvidéki családok igényeinek megfelelóen alakították át: kicsi lyukak, befalazott ablakok, tưzhely a lakrész közepén, kémény nélkül. A vízvezetékeket egészen ötletszerúen vezetik. A házban, ahol laktam, a csap az egykori udvaron, a mai baromfiudvaron található. Ide járnak mosakodni, itt mosnak. Más családoknál, ha van „fürdốszoba”, akkor nincs leválasztva, vagy legfeljebb egy függönnyel. A konyhában, a zuhanyozó közepén van egy lyuk: a vécé.

Nincs megoldva a szemétszállítás, a szemetet gyakran az utcasarkokon égetik el. Falun mindez egészen természetes: kevés szemét képzôdik, ennek egy részét - a trágyát, a rongyot - általában újra fölhasználják, a maradékot pedig a falu szélén, a kertek alján égetik el. Mennyi szemét keletkezik azonban egy olyan túlzsúfolt városban, mint Lima, csak egyetlen piacon, egyetlen nap! A belvárosban állandó a szemét és a füst savanykás, csípôs szaga.

Az utcán, a bárokban kizárólag waynut, a faluról a városba települt indiánok, a csólok zenéjét lehet hallani. Ez hasonló kulturális jelenség, mint a lakodalmas rock: nélkülözi a regionális eredetiséget, a népzenei hangzást a modernebb hangszerek adta lehetôségekkel egészítik ki - például dobgéppel; annyira leegyszerúsített a ritmus és a tánc koreográfiája, hogy kivétel nélkül mindenki tud rá táncolni. 
A kommunikáció általános nyelve viszont a spanyol maradt. Bár hallani az utcán sok kecsua szót is, ha két ismeretlen ember találkozik - például eladó és vevô, taxis és utas stb. -, biztos, hogy spanyolul szólítják meg egymást, még akkor is, ha mindkettójükön látszik, hogy a hegyvidékrôl származnak. Xavier Albó tanulmánya sem tud válaszolni arra, hogy vajon a lassú, de biztos asszimiláció lesz-e a bevándorlók sorsa, vagy ellenkezôleg: ốk hódítják-e meg a városokat (Albó 1979).

\section{Terrorizmus}

A terrorizmus és az ezzel járó állami megtorlások ideje, talán leáldozóban van. Ecuadorból, Chiléből, Bolíviából jószerével sohasem kapunk terrorizmussal kapcsolatos híreket, sốt, a kilencvenes évek elején azt hihettük, Peruban is vége az erôszakos politikai akciók és reakciók korának. A militáns mozgalmak mégsem múltak el fájó emlékek és napjainkig tartó következmények nélkül.

A quitói Nemzeti Gyújtemény egyik vezetố múvészettörténésze egy fiatal hölgy. Elsốsorban a hangszergyújtemény rendezésével foglalkozik, mellékállásban gyerekeket korrepetál. A kisfiával él. Férjét, az „Alfaro él, a k... életbe!” mozgalom harcosát a kormánykatonák ölték meg. Ố legalábbis így tudja. Hivatalosan errôl sohasem kapott értesítést. (A mozgalom névadója Eloy Alfaro, Ecuador elsố alacsony származású elnöke, a pozitivista gondolatok élharcosa.)

1993-ban Pinan felé félúton néhány fegyveressel találkoztunk. Utólag tudtam meg, hogy valószínúleg a kolumbiai Vörös Nap csoport tagjai voltak. Idegenvezetốmet (egy Cotacachi-beli dobkészítôt) állítólag még vörösfelkelố korából jól ismerték, de velem szemben bizalmatlanok voltak, amíg ki nem derült, hogy ismerem a Guantanamerát, és el nem énekeltem nekik - illetve velük. Majd a Venceremost és más dalokat is, végül az Internacionálét. Ez utóbbit ok nem 
ismerték, de megkértek rá, hogy küldjem el kazettán Cotacachiba, poste restante. (Nem tudom, megkapták-e.) Azóta is nehéz elképzelnem, hogy ez a nótás kedvú, vidám csapat olykor embereket mészárol.

Amikor hetekkel késóbb fölszálltunk a repülốre, egy napilapban azt a szalagcímet láttuk, hogy áldozatul esett öt terrorista. A kormánycsapatoknak nem esett vesztesége a harcban. A cikkhez tartozó képen ôserdei zaparo indiánok kiterített holttestét lehetett látni, teljes harci díszükben, színes tollkoronával fejükön. Fegyverük talán lándzsa lehetett. Felbujtott terroristák? Földjüket védő ôshonosok? Ki tudná ezt ilyen távolságból megmondani...

A közelmúlt egyik legsikeresebb perui filmje valós történeten alapul: valahol az Andok hegyláncai között egy katonatiszt el akar tussolni egy kisebb fegyelmi vétséget. Azt a megoldást választja, hogy antiterrorista különítményével elfogat minden környékbeli tanút, azaz az egész faluközösséget, egy bányába tereli óket, és a bányát rájuk robbantja.

Anamelva tizennégy évvel ezelôtt érkezett Magyarországra. Ösztöndíját egykor a Perui Kommunista Párton keresztül kapta meg. Peruban az ô családjánál töltöttem néhány napot: roppant kedves, ôshonos származású, limai család. Sokat meséltek a régi idôkrôl, amikor az utcán még egymást is csak álnéven szólították, röplapokat osztogattak, és különbözô akciókat készítettek elô, amíg csak a mi rendszerváltásunk ki nem húzta a lábuk alól az ideológiai talajt. Nem értik, miért fordítottunk hátat annak, amiért ok az illegalitásban küzdöttek.

Ecuadorban és Bolíviában végbement a nagy fordulat: a korábbi baloldali (tegyük hozzá: jórészt értelmiségi) terrorista mozgalmakat fölváltották az ôshonos paraszti lakosság érdekeinek képviseletét fölvállaló tömegmozgalmak. Céljuk már nem a hatalomátvétel kikényszerítése, hanem az, hogy legális választásokon szerezzék meg a hatalmat. Carlos Ivan Degregori mindezekrôl az andokbeli civil mozgalmakról nyújt átfogó ismertetést. Kiindulópontja a nyolcvanas 
évek vége: miért van az, hogy míg Ecuadorban és Bolíviában a társadalmi-kulturális ellentétek alapvetôen etnikai köntöst öltöttek, addig Peru belpolitikai életére a Fényes Ösvény, a Tupac Amaru és más radikális marxista forradalmi irányzatok nyomták rá a bélyegüket?

A kelet-európai olvasó valószínúleg kész a válasszal: azért, mert ténylegesen etnikai problémákról van szó, csak éppen Peruban ezeket az indulatokat a jól kiépült „forradalmi mozgalmak” tudták becsatornázni a hetvenes években. A szerzố azonban más, számunkra némiképp meghökkentố magyarázattal szolgál, amelyben szó esik az etnikai identitás megváltozásáról, a társadalmi rétegzôdésrốl, a társadalmi mozgalmak (civil szféra) belsố múködési logikájáról, a kulturális újratermelésrốl és a politika természetérôl. Egy biztos: ahol harcok dúltak, mindig az ôshonos közösségek szenvedtek a legtöbbet.

\section{A középosztály}

Mit keres Chile ebben a válogatásban? - kérdezheti joggal az olvasó, ha végigolvasta az ôshonosakról és még ôshonosabbakról szóló fejtegetéseket.

A hagyományos elképzelés szerint Dél-Amerika fehér, mesztic és indián övezetekre osztható, ahol a fehér övezetek (Argentína, Uruguay, Chile, Dél-Brazília) legalább annyira különböznek az indiántól (némi egyszerúsítéssel az ôserdố és az Andok vidéke), illetve a mesztictôl (Kolumbia, Venezuela és általában a tengerpartok), mint mindezek együtt az északi Nagy Testvértốl. Mint minden egyszerûsítés, természetesen ez a sztereotípia is segít egyfajta képet alkotni a vizsgált régióról, viszont elköveti azt a hibát, hogy kevés közös vonást mutató régiókat is egy kalap alá vesz, mint például az ôserdô és az Andok, a vadásztársadalmak és a földmúvelốk világa, amelyeknek történelem elốtti, állítólagos kapcsolatairól csak a nagyon finom 
érzékú kutatók mernek sejteni valamit, bizonyos mítoszok bizonytalan motívumtára alapján.

Hasonló egyszerúsítés Chilét a „fehér országok” között tárgyalni. Dél-Chile egészen a 18. század végéig az araukán törzsszövetség területe volt. Az Andokban ez a vidék állt ellen a legtovább a spanyoloknak. A magát pegucsének nevezó ôshonos nép ma is Chile jelentốs kisebbsége, lélekszáma talán az egymilliót is eléri. Chile csak viszonylag késôn, a múlt század utolsó negyedében egészült ki azokkal a területekkel, amelyek viszont történelmileg a Perui Alkirálysághoz, azt megelôzốen pedig Tawantinszujuhoz, az Inka Birodalomhoz tartoztak, és mint ilyenek, jelentốs kecsua és ajmara ôshonos népességgel rendelkeztek. Az, hogy Chile ma lakosai többségét tekintve valóban fehér ország, sokkal inkább köszönhetố a századfordulótól az ötvenes évekig tartó európai bevándorlásnak (amely persze, ha kisebb mértékben is, de a többi andokbeli országot is érintette). A helyzet tehát egészen más, mint például az argentin pampákon, ahol az ôslakosságot Roca tábornok hadjárata során kiirtották, szabaddá téve az utat a telepes cowboyok helyi változata, a gauchok és a vaquerok elốtt.

Chile nem atipikus andokbeli ország, hanem az egyetlen az andokbeliek közül, amelynek sikerült véghezvinni a középosztályosodásként elképzelt meszticizálódás százötven éves programját. Larissa Adler Lomnitz ennek a chilei városi középosztálynak a leírására vállalkozik a tôle megszokott egyéni módszerrel és hosszabb teoretikus hivatkozásokkal (egyebek közt) Polányira, Sahlinsre, Gouldnerre, Bohannanra és Blaura (Adler Lomnitz 1994). Adler Lomnitz ma már klasszikusnak számító chilei társadalomkutató, aki mind amerikai tanulmányai, mind késôbbi tevékenysége révén sok szállal kötốdik a társadalomkutatás nemzetközi élvonalához. Munkássága nagyon nehezen sorolható kategóriákba: hálózatelemzéssel foglalkozik, de nem Granovetter alapján, és a módszertant csupán arra használja, hogy olyan szociológiai kérdéseket vizsgáljon, amelyek neki mint antropológusnak nem képezik szakterületét. A közép- 
osztály kiépülését (kiépítését) konstruktivista alapokról történeti folyamatnak tekinti. Leírja, miként alakult ki az a városi lakosság, amely nem palotában lakott, hanem házban és nem tartotta szégyennek a munkával való pénzkeresetet; miként sikerült anyagi alapot adni a középosztálynak 1883-ban a salétromvidék elfoglalásával és számukra kedvezô privatizációjával; hogyan erôsítették meg a középosztály sorait és a kifehéredés tendenciáját az országba csábított európaiakkal, és hogyan kerülték el a középosztályosodásra kevéssé hajlamos ázsiai bevándorlók tömegeit; végül pedig, hogy miként sikerült megmenteni a középosztályt mind a gazdasági válság okozta (törvényszerúnek tartott) lesüllyedéstôl, mind az arisztokrácia ellentámadásától, mind pedig a proletárdiktatúrától. Chilei középosztály már van, miközben a többi andokbeli országban a középosztály még éppen csak formálódik. Mi ennek a középosztálybeliségnek a tartalma? A hálózatelemzésen alapuló magyarázat szerint a középosztálybeliség nem egy képzelt ál lapot, nem is pusztán egy valós társadalmi helyzet, hanem hozzáférés bizonyos jellegú társadalmi kapcsolatokhoz és a fölöttük való rendelkezés. A válogatásunkban közölt tanulmány ezt a sajátosan középosztálybeli hálózatot igyekszik minél alaposabban föltárni: milyen jellegú kapcsolatok alkotják, milyenfajta szolgáltatások vehetôk igénybe, hol húzódnak e kapcsolatrendszerek (hálók) határai. A tanulmány megértését szemléletes ábrák teszik könnyebbé (vagy nehezebbé). A cikk megállapításai nagy valószínúséggel érvényesek a többi andokbeli ország szélesedô középosztályára is, és hasonló kutatásokra ösztönözhetnek a mi térségünkben is. 